\section{CarakaTanii \\ Journal of Sustainable Agriculture \\ ISSN 2613-9456 (Print) 2599-2570 (Online)}

\title{
The Characteristics of Striped Catfish Oil (Pangasius hypophthalmus) Extracted by Dry Rendering Method at Different Temperatures
}

\author{
Dhita Ulfi Lestari, Sumardianto and Lukita Purnamayati* \\ Department of Fish Product Technology, Faculty of Fisheries and Marine Science, \\ Universitas Diponegoro, Semarang, Indonesia \\ *Corresponding author: lukita.purnamayati@live.undip.ac.id
}

\begin{abstract}
Striped catfish (Pangasius hypophthalmus) is a high-fat fish compared to other freshwater fish like snakehead fish and carp. Striped catfish oil contains unsaturated and polyunsaturated fatty acids that are beneficial for health. The quality of catfish oil is affected by the extraction method, especially the preliminary heating temperature for the extraction. This study aimed to determine the effect of different heating temperatures on the characteristics of catfish oil and find the best heating temperature in the dry rendering process. This study used a completely randomized design with three different heating temperatures $\left(80^{\circ} \mathrm{C}, 100^{\circ} \mathrm{C}\right.$ and $\left.120^{\circ} \mathrm{C}\right)$. The result showed that the extraction at various temperatures was significantly different on the yield, moisture content, peroxide value, iodine value, free fatty acids value and slip melting point, but not significantly different in sensory properties. A higher heating temperature could increase the yield percentage, free fatty acids values, peroxide values, iodine values, except to the moisture contents, slip melting point and fatty acid profiles. The best temperature was $100^{\circ} \mathrm{C}$ for 20 minutes with $9.09 \%$ yield, $1.44 \%$ moisture content, $1.72 \%$ free fatty acid, $15.82 \%$ iodine value and sensory of $7.65<\mu<8.15$. Based on the results, it can be concluded that the dry rendering temperature affects the characteristics of the catfish oil.
\end{abstract}

Keywords: dry rendering; fish oil; striped catfish; temperature

Cite this as: Lestari, D. U., Sumardianto, \& Purnamayati, L. (2020). The Characteristics of Striped Catfish Oil (Pangasius hypophthalmus) Extracted by Dry Rendering Method at Different Temperatures. Caraka Tani: Journal of Sustainable Agriculture, 35(1), 66-77. doi: http://dx.doi.org/10.20961/carakatani.v35i1.31604

\section{INTRODUCTION}

The fisheries sector is one of agricultural aspects which support foodstuff diversity (FAO, 2018). Food safety and nutrition are some of the regional actions encouraged by FAO on the fisheries and agricultural sector through good agricultural practices (FAO, 2018). Fisheries products play an essential role in supplying the animal protein intake through the export products from the developing countries (JICA, 2016); one of them is catfish. Striped catfish (Pangasius hypophthalmus) is one of the high demands for freshwater fish in Indonesia. The production rate for export had increased from 339,069 tons in
2015 to 437,111 tons in 2016 . This rate was expected to grow as the Indonesian Ministry of Fisheries and Maritime Affairs targeted the production of catfish at around 600,000 tons in 2018 (Arika, 2018). According to Panagan et al. (2011), catfish contains $16.08 \%$ of protein, $5.75 \%$ of lipid, $1.5 \%$ of carbohydrate, $0.97 \%$ of ash and $75.7 \%$ of moisture. The lipid contents of other freshwater fish such as snakehead fish and carp are $4.0 \%$ and $2.9 \%$, respectively. Striped catfish is categorized as high-fat fish. Lestari (2010) stated that the lipid content in catfish reaches $40 \%$, while Hashim et al. (2015) stated that catfish contains crude fat ranging from $24 \%$ to $37.7 \%$.

\footnotetext{
* Received for publication July 1, 2019

Accepted after corrections November 27, 2019
} 
Striped catfish oil is a source of omega-3, omega-6 and omega- 9 unsaturated fatty acids, amounting to $3.1-4.7 \%, 12.8-13.9 \%$ and $35.0-$ 41.4\%; respectively (Hashim et al., 2015). Omega 3 fatty acids in fish oil have many health benefits. Omega-3 and omega- 6 form eicosanoids have specific functions on tissues, including inhibiting aggregation, anti-inflammatory and regulating cholesterol intake in tissues (Kus-Yamashita et al., 2016) while omega-9 non-essential fatty acids play a role in reducing low-density lipoprotein (LDL) and increasing high-density lipoprotein (HDL) in the blood (Kamini et al., 2016).

Pike and Jackson (2010) stated that fish oil could be applied directly to food products to cover the fishy smell. Some studies have used fish oil as a food additive by adding it to yogurt (Zhong et al., 2018), butter (Subroto et al., 2018) and bakery products such as cakes (Santhanam et al., 2015). Fish oil mixed with vegetable oil can enrich omega-3 fatty acids, like virgin coconut oil (Apraku et al., 2017), linseed oil and palm oil (Monge-Ortiz et al., 2018).

Oil extraction is affected by several factors, including the extraction method, temperature, preliminary treatment, particle size and contact time of the material with the solvent (Ghazali and Yasin, 2016). The fish oil extraction method is generally carried out by the rendering method with heating. Dry rendering extraction is a method of extracting oil by preheating (without adding water) before oil separation and then continued with pressing. Preliminary heating aims to damage the membrane and cell walls of lipid tissue in the material so that the oil will be released and easy to extract (Ambrosewiczwalacik et al., 2015). Kamini et al. (2016) stated that the interaction between temperature and extraction time do not affect the yield of oil produced. The yield value will increase along with the heating temperature. However, the chemical characteristics of oil, including free fatty acids, peroxide, $\mathrm{p}$-Anisidine and totox value, will also increase. Therefore, the quality of the oil obtained will decrease. Rozi et al. (2016) specified that extraction of slit-eye shark liver oil at $50-80^{\circ} \mathrm{C}$ for 8 hours produces fish oil below IFOS (International Fish Oil Standard). Saleem and Ahmad (2018) detailed that pre-heating at 110$250^{\circ} \mathrm{C}$ for 30 minutes will increase oxidation as the temperatures rise (Saleem and Ahmad, 2018). Therefore, the heating temperature of the pre- treatment in the dry rendering process is an essential factor.

According to Estiasih (2009), temperature and the duration of extraction will trigger more formation of secondary oxidation due to the decomposition process, which can break the hydroperoxide compound. Nurjanah et al. (2014) stated that the different temperature ratio puts a significant effect on the percentage of the yield from the catfish skin and it has led to further research on the optimum temperature used in extracting oil from catfish. Therefore, the objective of this study was to determine the physical, chemical and sensory characteristics of catfish oil extracted at different preheating temperatures $\left(80^{\circ} \mathrm{C}, 100^{\circ} \mathrm{C}\right.$ and $\left.120^{\circ} \mathrm{C}\right)$, as well as find the best preliminary heating temperatures in the dry rendering process.

\section{MATERIALS AND METHOD}

\section{Materials}

Raw materials used in this study were fresh striped catfish (Pangasius hypophthalmus) from farmers in Pekalongan, Central Java. One $\mathrm{kg}$ catfish were used, each with an average length of $49 \mathrm{~cm}$ and a width of $11.5 \mathrm{~cm}$. The raw materials were put into styrofoam boxes, filled with ice cubes bulk with a ratio of 1:1 fish and ice maintained the cold chain system to preserve the quality. Fresh catfish were transported by car to the laboratory, then stored in the freezer until the fish oil production started.

\section{Equipment}

The equipment used in the production of catfish oil was ovens, baking sheets, cornucopia, hydraulic press, digital scales, alarm cups, measuring cups, water baths and sample bottles.

\section{Extraction of striped catfish oil}

The procedure of fish oil extraction by the dry rendering method referred to the modified procedure by Kamini et al. (2016). The fresh catfish were gutted, beheaded and washed. Clean catfish then were cut into fillets (without skin and bones) and mashed using a grinder. The minced fish $(120 \mathrm{~g})$ were put into a baking sheet that had been coated with transparent cloth, then heated in an oven at various temperatures, $80^{\circ} \mathrm{C}, 100^{\circ} \mathrm{C}$ and $120^{\circ} \mathrm{C}$ for 20 minutes. After being removed from the oven, the samples were pressed using a hydraulic press. Extracted oils were then stored in 
dark beaker glasses and coated with aluminum foil.

\section{Yield of oil}

Fish oil yield (\%) was the ratio of the weight of fish oil produced $(\mathrm{g})$ with the weight of the sample used (g) multiplied by $100 \%$ (Association of Analytical Communities, 1995).

\section{Moisture content}

The calculation of moisture content was carried out based on the Association of Analytical Communities (2007). About $1 \mathrm{~g}$ of fish oil samples were dried in an oven at $100-105^{\circ} \mathrm{C}$ for 3 hours, rested on desiccator and weighed. The samples were then reheated in the oven for 30 minutes, put again on desiccator and weighed. These treatments were repeated until a constant weight was achieved. Moisture content was calculated by dividing the weight of the samples after heated by the sample weight before heating then multiplied by $100 \%$

\section{Slip melting point (SMP)}

The SMP test was based on the Association of Analytical Communities (1997) by dipping the capillary tube into the oil until the sample rose \pm $10 \mathrm{~mm}$. Samples in capillary pipes were chilled in a refrigerator at $4-10^{\circ} \mathrm{C}$ for 16 hours. The capillary pipes were tied to the thermometer, then the bottom of the thermometer was inserted into distilled water in a $600 \mathrm{ml}$ cup. The initial temperature of distilled water was kept at $8-10^{\circ} \mathrm{C}$ below the slip point sample. The process was conducted in the water bath. The water was stirred with little airflow, while the temperature raised gradually, the fat became clear before melting perfectly. The heating continued until the contents of the capillary tube became clear. The temperature showed in a clear capillary tube was the melting point of fat or oil.

\section{Iodine value}

The iodine value test was conducted based on Badan Standardisasi Nasional (1998). Around 0.1 $\mathrm{g}$ of fish oil were weighed into $250 \mathrm{ml}$ of erlenmeyer, then $10 \mathrm{ml}$ of chloroform and $25 \mathrm{ml}$ of iodine-bromide reagent were added and left in a dark room for 30 minutes. A $15 \%$ KI solution and distilled water were added for $10 \mathrm{ml}$ and 50$100 \mathrm{ml}$, respectively, then immediately added with sodium thiosulfate solution $\left(\mathrm{Na}_{2} \mathrm{~S}_{2} \mathrm{O}_{3} 0.1 \mathrm{~N}\right)$ until the color turned into pale yellow. A $2 \mathrm{ml}$ of starch solution was added and the titration continued until the blue color disappeared. A blank solution was made from $25 \mathrm{ml}$ of iodinebromide reagent and $10 \mathrm{ml}$ of $15 \% \mathrm{KI}$ was diluted with $100 \mathrm{ml}$ of distilled water, which had been boiled and titrated with sodium thiosulfate solution. The amount of sodium thiosulfate used for titrating blanks minus the titration in the sample was equivalent to the amount of iodine bound by fat or oil.

\section{Fatty acid profile}

Analysis of fatty acids profile was based on the Association of Analytical Communities (2005) by extracting fatty acids using a Soxhlet apparatus. The oil obtained was then weighed for $20-40 \mathrm{mg}$ of $\mathrm{NaOH} 0.5 \mathrm{~N}$ in methanol and heated in a water bath for 20 minutes. BF3 20\% (2 ml) was added after it was cooled. Two ml saturated $\mathrm{NaCl}$ and 1 $\mathrm{ml}$ hexane were also added and shaken until homogeneous. The hexane layer was transferred with a dropper pipette into a tube containing $0.1 \mathrm{~g}$ of $\mathrm{Na}_{2} \mathrm{SO}_{4}$ anhydrous and left for 15 minutes. The liquid phase was separated and injected into the GC. Identification of fatty acids was performed by injecting methyl ester in gas chromatography with a mobile phase and pressurized nitrogen for $20 \mathrm{ml}$ minute $^{-1}$. A capillary column Quadrex fused silica capillary column 007 cyanopropyl methyl silica, $60 \mathrm{~m}$ in length and $0.25 \mathrm{~mm}$ of diameter was used.

\section{Peroxide value}

A total of $5 \mathrm{~g}$ of fish oil were put into $250 \mathrm{ml}$ of erlenmeyer, then added with $30 \mathrm{ml}$ of aceticchloroform acid solution (3:2) and shaken until dissolved. Saturated KI solution $(0.5 \mathrm{ml})$ was added in the erlenmeyer in sealed conditions, left for 1 minute while shaken. After that, $30 \mathrm{ml}$ of distilled water was added and titrated with $0.01 \mathrm{~N}$ $\mathrm{Na}_{2} \mathrm{~S}_{2} \mathrm{O}_{3}$ until the yellow color almost disappeared. A total of $0.5 \mathrm{ml}$ of $1 \%$ starch solution was added and titrated again until the blue color began to disappear. The peroxides value was expressed in milli-equivalents of peroxide in every $1000 \mathrm{~g}$ of the sample (Association of Analytical Communities, 1995).

\section{Free fatty acid value}

A total of $14 \mathrm{~g}$ of fish oil were put into $250 \mathrm{ml}$ erlenmeyer and $25 \mathrm{ml}$ of $95 \%$ ethanol was added and heated at $40^{\circ} \mathrm{C}$. After that, $2 \mathrm{ml}$ of PP indicator was added and titrated with $0.1 \mathrm{~N} \mathrm{KOH}$ solution until the pink color appeared and did not disappear for 30 seconds (Association of Analytical Communities, 1995). 


\section{Sensory evaluation}

The sensory evaluation method in this study using a score sheet of crude sardine fish oil (SNI: 7950:2013) in Appendix 8 by 30 panelists with a rating scale of 1-9; 9 for good quality indicated by the bright appearance, clean, brownish-yellow oil and a very strong specific odor of fish oil, while 1 for poor quality indicated by dirty appearance, deep black and rancid odor (Badan Standardisasi Nasional, 2011).

\section{Statistical analysis}

This study used a completely randomized design with one factor of different extraction temperatures. Data were analyzed using ANOVA. Further tests were carried out by the Tukey test if there were significant differences $(\alpha<0.05)$.

\section{RESULTS AND DISCUSSION}

\section{Yield of oil}

Yield percentage is a percentage of the oil content obtained from fish extraction. The percentage of yield in this study was the ratio between the yield of extracted fish oil and the initial weight of the minced fish used. The results of the yield percentage with different extraction temperatures are presented in Table 1.

Table 1. The yield of striped catfish oil with different extraction temperatures

\begin{tabular}{cc}
\hline Extraction temperature $\left({ }^{\circ} \mathrm{C}\right)$ & Yield $(\%)$ \\
\hline 80 & $8.73 \pm 1.10^{\mathrm{b}}$ \\
100 & $9.09 \pm 0.89^{\mathrm{b}}$ \\
120 & $12.40 \pm 0.53^{\mathrm{a}}$ \\
\hline
\end{tabular}

Note: Data \pm standard deviation. The same superscript in the same column shows non-significant difference at the $5 \%$ level

The different extraction temperatures produced different yields. The yields ranged from $8.73 \%$ to $12.40 \%$, with the highest yield obtained at $120^{\circ} \mathrm{C}$. This result was higher than the yield of skipjack tuna fish, which was amounted to be $1.0 \%$ (Aditia et al., 2014). The results showed that the higher temperatures would produce higher yields because the heating process could damage the cell wall and extracted the oil. According to Nugroho et al. (2014), low heating temperature $\left(<60^{\circ} \mathrm{C}\right)$ determined that low amounts of proteins were denatured, which made the cell walls more difficult for oil to penetrate in the material, while higher temperatures caused proteins to undergo the denaturation process.
The amount of yield produced in fish oil could also be influenced by feed. The high-fat content in feed would have an impact on the high levels of fat in the fish. According to Haryati (2011), increased fat content in feed consumed by fish might result in increasing lipid content. Nurjanah et al. (2014) also stated that the fish oil content in catfish depends on many factors, including season and gender, while the lipid content may vary in each part of the body depending on the movement, size of the pond and feed.

\section{Slip melting point (SMP)}

An SMP is one of the physical tests to determine the melting point of the oil. Melting point can determine other physical qualities like hardness and thermal characteristics of oil and fat (Hasibuan and Siahaan, 2013). The results of the SMP in striped catfish oil with different extraction temperatures are presented in Table 2.

Table 2. The SMP

\begin{tabular}{cc}
\hline Extraction temperature $\left({ }^{\circ} \mathrm{C}\right)$ & $\mathrm{SMP}\left({ }^{\circ} \mathrm{C}\right)$ \\
\hline 80 & $37.00 \pm 1.00^{\mathrm{a}}$ \\
100 & $34.33 \pm 1.53^{\mathrm{a}}$ \\
120 & $32.67 \pm 1.15^{\mathrm{b}}$ \\
\hline
\end{tabular}

Note: Data \pm standard deviation. The same superscript in the same column shows non-significant difference at the $5 \%$ level

The highest result was obtained at $80^{\circ} \mathrm{C}$ and the melting point of fish oil was $37^{\circ} \mathrm{C}$, which showed that at that temperature, fish oil had a higher saturation level than at the other temperatures. According to Ngadiarti et al. (2013), the melting point of the oil is related to the unsaturated fatty acid content, the higher unsaturated bonds and the lower melting point. Striped catfish oil was in solid at room temperature of $25-29^{\circ} \mathrm{C}$. This is due to the small double bond in the carbon atomic chain or encountered hydrogenation. According to Suroso (2013), oil has more than two double bonds in the liquid phase and when hydrogenated at the double bond, it changed to solid at room temperature. Hydrogenation is the process of adding hydrogen to the double bonds of the oil carbon atom chain, which can reduce the level of oil or fatty acid unsaturation.

The results of the SMP showed that the lowest value was at $120^{\circ} \mathrm{C}$. This result was higher if compared to the melting point of catfish oil, which ranged from $23-30^{\circ} \mathrm{C}$ (Ulfah et al., 2016). It 
indicates that striped catfish oil is more saturated than catfish oil. Compared to palm oil, striped catfish oil has a lower melting point than palm oil, which is $39.12-40.68^{\circ} \mathrm{C}$ (Wulandari et at., 2011) and palm oil is more saturated than catfish oil. According to Ngadiarti et al. (2013), the melting point is related to the chemical structure of fatty acids. The melting point of saturated fatty acids (SFA) will increase along with chain length, while the melting point of unsaturated fatty acids will be lower as the number of fatty acids double bonds increases. According to Ulfah et al. (2016), the melting point is influenced by the chain length of fatty acids, the number of double bonds and the degree of unsaturation.

\section{Iodine value}

Iodine value indicates the degree of unsaturation of a fat or oil. The higher the iodine number, the higher the degree of unsaturation and the quality of the oil. Iodine value can be used as an indicator to measure the number of double bonds. The amount of iodine absorbed indicates the number of double bonds or unsaturated bonds (Handajani et al., 2010). The iodine values in striped catfish oil with different extraction temperatures are presented in Table 3.

Table 3. Iodine value in striped catfish oil with different extraction temperatures

\begin{tabular}{cc}
\hline Extraction temperature $\left({ }^{\circ} \mathrm{C}\right)$ & Iodine value $(\%)$ \\
\hline 80 & $13.76 \pm 0.30^{\mathrm{c}}$ \\
100 & $15.82 \pm 1.12^{\mathrm{b}}$ \\
120 & $17.93 \pm 0.73^{\mathrm{a}}$ \\
\hline
\end{tabular}

Note: Data \pm standard deviation. The same superscript in the same column shows non-significant difference at the $5 \%$ level

As presented in Table 3, the highest number of iodine was at $120^{\circ} \mathrm{C}$ for $17.93 \%$. The result was lower compared to the standard iodine value by Badan Standardisasi Nasional (2013) for crude sardine fish oil, which is $140-160 \%$. It showed that the extracted catfish oil had a low degree of unsaturation fatty acids as a result of the small double bonds. According to Hasibuan (2012), iodine value is used to determine the unsaturation of oil. The iodine number shows the number of double bonds of fatty acids. The number of double bonds and a high degree of unsaturated oil are due to higher numbers of iodine. The result of iodine value in this study was higher than the iodine of fish oil from the intestinal of tilapia, approxi- mately $9.13 \%$ at $80^{\circ} \mathrm{C}$ (Nugroho et al., 2014). When the iodine number is higher, the quality is also improved.

The iodine value was related to the melting point of fish oil. According to Hasibuan (2012), the more unsaturated fatty acids with a double bond, the fish oil would be more liquid and vice versa. The form would solidify if the saturated fatty acid values were high. It was followed by the results of the SMP in this study. The temperature of $120^{\circ} \mathrm{C}$ produced the highest iodine number compared to other temperatures, indicating that the melting point of fish oil at this temperature was lower than those of the other temperatures. It confirmed that the SMP also showed the lowest value compared to other temperatures and fish oil would melt quickly. This study has disclosed that high the iodine value was affected by the high extraction temperature. This study also shows that the highest extraction temperature, $120^{\circ} \mathrm{C}$ had more double bonds. It followed Hidayati (2007) that an increase in temperature would increase the iodine number.

\section{Fatty acid profile}

Fatty acid profiles were performed to determine the composition of SFA, monounsaturated fatty acids (MUFA) and double unsaturated fatty acids or polyunsaturated fatty acids (PUFA). The results of fatty acid profiles in striped catfish oil with different extraction temperatures are presented in Table 4.

Fatty acid profiles in striped catfish oil showed higher SFA compared to unsaturated fatty acids. The temperature of $80^{\circ} \mathrm{C}$ produced the highest percentage of SFA, equal to $46.09 \%$. At the temperature of $100^{\circ} \mathrm{C}$, it had additional lauric and arachidic acids, but the percentage was small. It also had a lower percentage of SFA at $120^{\circ} \mathrm{C}$. It followed Azka et al. (2015) that SFA had the highest value compared to other fatty acids because SFA was needed as energy.

SFA dominated the fish oil, followed by MUFA and PUFA. The percentage of saturated fatty acid profiles from striped catfish oil obtained from this study followed Hashim et al. (2015), that palmitic acid is the dominant saturated fatty acid. The oleic, palmitoleic and arachidonic fatty acids are typical characteristics of fish oil derived from freshwater fish. According to Thammapat et al. (2010), the SFA content in catfish ranged from $30.2 \%$ to $6.5 \%$ and was dominated by palmitic acid and stearic acids. 
MUFA contained in striped catfish oil was omega-9 (oleate), which had a high percentage of 30-34\%; Catfish oil also contained omega-3 (linolenic) and omega-6 (linoleic). According to Sartika (2008), omega-9 could reduce cholesterol levels. PUFAs (arachidonic, linoleic and linolenic fatty acids) played essential roles in transporting and fat metabolism, immune functions, maintaining cell membrane function and integrity. Omega-3 fatty acids could prevent coronary heart disease and arthritis.

Table 4. Fatty acid profiles in striped catfish oil with different extraction temperatures

\begin{tabular}{lcrrr}
\hline \multirow{2}{*}{ Fatty acid } & \multirow{2}{*}{ Structure } & \multicolumn{3}{c}{ Relative fatty acids percentage $(\%)$} \\
\cline { 3 - 5 } & & $80^{\circ} \mathrm{C}$ & $100^{\circ} \mathrm{C}$ & $120^{\circ} \mathrm{C}$ \\
\hline Palmitic acid & $(\mathrm{C} 16: 0)$ & 32.43 & 30.58 & 30.67 \\
Stearic acid & $(\mathrm{C} 18: 0)$ & 8.30 & 7.77 & 7.47 \\
Myristic acid & $(\mathrm{C} 14: 0)$ & 5.22 & 5.53 & 7.08 \\
Lauric acid & $(\mathrm{C} 12: 0)$ & - & 0.27 & - \\
arachidic acid & & 0.14 & 0.18 & - \\
\hline Total SFA & & 46.09 & 44.33 & 45.22 \\
\hline Oleic acid & $(\mathrm{C} 18: 1)$ & 30.66 & 34.18 & 34.63 \\
Palmitoleic acid & $(\mathrm{C} 16: 1)$ & 4.82 & 3.01 & 3.39 \\
\hline Total MUFA & & 35.48 & 37.19 & 38.02 \\
\hline Linoleic acid & $(\mathrm{C} 18: 2)$ & 11.39 & 11.87 & 11.35 \\
Linolenic acid & $(\mathrm{C} 18: 3)$ & 0.52 & 0.79 & 0.65 \\
\hline Total PUFA & & 11.91 & 12.66 & 12.00 \\
\hline Total SFA, MUFA and PUFA & & 93.48 & 94.18 & 95.24 \\
\hline
\end{tabular}

Monosaturated fatty acids (MUFA) oleic fatty acids were the highest yield. According to Nurjanah et al. (2014), the monounsaturated oleic fatty acid is an essential fatty acid, because it acts as a precursor of omega-3 fatty acids in animals. In general, the fatty acid composition of fish oil varies depending on eating habits, environmental conditions, age, the maturity of gonads and species (Hastarini et al., 2012).

\section{Peroxide value}

Peroxide value in crude fish oil is the degree of the reactions that may occur. Peroxide value is essential to indicate the level of damage in fish oil. The results of peroxide value in striped catfish oil with different extraction temperatures are presented in Table 5.

Table 5. Peroxide values in striped catfish oil with different extraction temperatures

\begin{tabular}{cc}
\hline $\begin{array}{c}\text { Extraction temperature } \\
\left({ }^{\circ} \mathrm{C}\right)\end{array}$ & $\begin{array}{c}\text { Peroxide value } \\
\left(\mathrm{meq} \mathrm{kg}^{-1}\right)\end{array}$ \\
\hline 80 & $3.15 \pm 2.06^{\mathrm{c}}$ \\
100 & $6.40 \pm 0.54^{\mathrm{b}}$ \\
120 & $11.59 \pm 0.10^{\mathrm{a}}$ \\
\hline
\end{tabular}

Note: Data \pm standard deviation. The same superscript in the same column shows non-significant difference at the $5 \%$ level
Table 5 demonstrates that the lower temperature in the extraction could reduce the value of peroxide in the crude fish oil. The lowest average of peroxide was found at a temperature of $80^{\circ} \mathrm{C}$, which was $3.15 \mathrm{meq} \mathrm{kg}^{-1}$. This result followed the Indonesian National Standard (SNI, Standar Nasional Indonesia) of Crude Sardine Fish Oil for peroxide value of 4-5 meq $\mathrm{kg}^{-1}$ (Badan Standardisasi Nasional, 2013). The peroxide values of catfish oil at $100^{\circ} \mathrm{C}$ and $120^{\circ} \mathrm{C}$ in this study were high, $6.40 \mathrm{meq} \mathrm{kg}^{-1}$ and 11.59 meq $\mathrm{kg}^{-1}$, respectively. These results also met the IFOMA (International Fishmeal and Oil Manufacturers Association), the standard peroxide value of crude fish oil is 3-20 meq kg-1 (Bimbo, 1998). Compared to Suseno et al. (2016), pre-purified sardine and shark fish oil had peroxide values of 30.84 meq $\mathrm{kg}^{-1}$ and 17.56 meq $\mathrm{kg}^{-1}$, respectively, the peroxide value of striped catfish oil in this study was much lower.

The low quality of fish oil might be caused by the conditions of raw materials processed in high temperatures. The quality of raw materials and the presence of thermal processes enabled hydrolysis and oxidation occurred in fish oil. Also, the storage period would affect oil quality. During the storage, the oxidative damage was formed and broke the double bonds in the fatty acid chain. 
Fish oil with high peroxide numbers indicated that the oil was not properly processed and stored and this led to excessive oxidation. According to Edward et al. (2011), oil has increased peroxide numbers due to the breakdown of double bonds caused by heating temperatures. The lower the peroxide number in fish oil is, the better the quality will be. It followed the statement by Panagan et al. (2011), the peroxide number is smaller, the quality is better.

High peroxide value indicated that oxidized oil had a rancid odor. The oxidation process occurred when unsaturated fatty acids bond oxygen to their double bonds and form hydroperoxide or known as peroxide. The breakdown of the peroxide compound would form aldehydes, ketones and free fatty acids, which were identified as unpleasant smells. Therefore, the level of oil damage can be measured by determining the number of peroxide compounds formed in the oil. According to Azizah et al. (2016), the oxidation reaction in the oil would initially form peroxide and hydroperoxide and then turn into aldehydes, ketones and free fatty acids. Rancidity was formed by the presence of aldehydes, instead of peroxide. Thus, the higher peroxide number is an indicator that causes rancidity. Unsaturated fatty acids bind oxygen to their double bonds to form peroxide. Peroxide is the initial product of an unstable oxidation reaction and this reaction can take place if there is a contact between oxygen and oil. Measuring peroxide value can be used to determine the level of oil rancidity.

\section{Moisture content}

Moisture content is one of the most important quality standards for crude fish oil. According to Suroso (2013), the primary determinant of oil level damage is moisture content because the presence of water makes the oil more natural to undergo the hydrolysis process, which is the beginning of decomposition. The oil that contains more water increases its hydrolysis. It determines the water physically bond to oil. Water can be separated from oil through drying with an oven at a temperature of $100-105^{\circ} \mathrm{C}$. The results of the moisture content of crude striped catfish oil extracted from different temperatures are presented in Table 6.

The results showed that the lower the extraction temperature was, the higher the moisture content would be. The lowest moisture contents were obtained at $120^{\circ} \mathrm{C}$ for $0.08 \%$ and $100^{\circ} \mathrm{C}$ for $1.44 \%$. These results of the moisture contents followed the SNI of Crude Sardine Fish Oil, with a maximum of $2 \%$ moisture content (Badan Standardisasi Nasional, 2013). The result of the moisture content at $80^{\circ} \mathrm{C}$ was $4.02 \%$, which did not meet the standard if compared to the result of the moisture content of fish oil from Tilapia intestinal waste.

Table 6. Moisture content of striped catfish oil with different extraction temperatures

\begin{tabular}{cc}
$\begin{array}{c}\text { Extraction temperature } \\
\left({ }^{\circ} \mathrm{C}\right)\end{array}$ & $\begin{array}{c}\text { Moisture content } \\
(\%)\end{array}$ \\
\hline 80 & $4.02 \pm 0.04^{\mathrm{a}}$ \\
100 & $1.44 \pm 0.07^{\mathrm{b}}$ \\
120 & $0.08 \pm 0.02^{\mathrm{c}}$ \\
\hline
\end{tabular}

Note: Data \pm standard deviation. The same superscript in the same column shows non-significant difference at the $5 \%$ level

The study by Nugroho et al. (2014) revealed that the moisture content of oil from Tilapia intestinal ranged from $0.88 \%$ to $1.14 \%$. Therefore, the moisture content of striped catfish in this study was high. High moisture content in fish oil would reduce the quality of fish oil as a result of the hydrolysis reaction, which made free fatty acid content levels increased. According to Aditia et al. (2014), the high moisture content in fish oil would reduce the quality of fish oil because of the ability of water to hydrolyze oil. Finally, free fatty acids would be formed, which resulted in rancidity of fish oil.

\section{Free fatty acids}

Free fatty acids value is one of the parameters to determine the quality of fish oil, which is connected to the storage process. The value of free fatty acids is the content of fatty acids that are not in the form of triglycerides and is used to measure the amount of free fatty acids contained in the oil. High-quality oils have low free fatty acids (Suroso, 2013). The results of free fatty acids value in catfish oil with different extraction temperatures are presented in Table 7.

The data disclosed that the value of free fatty acids increased as the temperatures increased. The higher free fatty acids in oil refer to low quality (Eka et al., 2016). The results of this study showed that the lowest free fatty acid value was obtained at $80^{\circ} \mathrm{C}$ for $1.45 \%$. This met the SNI, that crude sardine fish oil should contain 1-2\% free fatty acid value (Badan Standardisasi Nasional, 2013). The 
number of free fatty acids at $100^{\circ} \mathrm{C}$ was not significantly different from the number of fatty acids at the temperature of $80^{\circ} \mathrm{C}$, which was $1.72 \%$; this value also met the SNI. It was different from the value of free fatty acids obtained at $120^{\circ} \mathrm{C}$ as the highest in this study for $2.40 \%$. This value was above SNI but met IFOMA standards, $1-7 \%$ free fatty acids (Bimbo, 1998). The results of free fatty acids values of striped catfish oil in this study were lower compared to the values of shark fish oil, which was $4.83 \%$. The heating process might cause increased free fatty acid content. According to Suseno et al. (2016), the high level of free fatty acids due to the low quality of raw materials, the thermal process allowed fish oil to hydrolyzed faster and the high moisture content caused the hydrolysis and oxidation.

Table 7. Free fatty acid value in striped catfish oil with different extraction temperatures

\begin{tabular}{cc}
\hline $\begin{array}{c}\text { Extraction temperature } \\
\left({ }^{\circ} \mathrm{C}\right)\end{array}$ & $\begin{array}{c}\text { Free fatty acids } \\
(\%)\end{array}$ \\
\hline 80 & $1.45 \pm 0.41^{\mathrm{b}}$ \\
100 & $1.72 \pm 0.34^{\mathrm{b}}$ \\
120 & $2.40 \pm 0.24^{\mathrm{a}}$ \\
\hline
\end{tabular}

Note: Data \pm standard deviation. The same superscript in the same column shows non-significant difference at the $5 \%$ level

The heating process in the extraction leads to the formation of free fatty acids in fish oil. A carbon chain with double bonds in unsaturated fatty acids would react with heat to form free fatty acids that affected the quality of fish oil. According to Nugroho et al. (2014), if the extraction temperature is higher, there will be more free fatty acids formed due to the high temperature. More carbon chains in the double oil bonds will be broken and then form free fatty acids - the higher the acid number is, the lower the quality of the oil will be.

\section{Sensory}

Organoleptic properties were an evaluation method that use human senses to measure the texture, appearance, aroma and flavor of food products, in this case, was fisheries product (Eka et al., 2016). The results of the organoleptic test in this study indicated that the treatment of different extraction temperatures did not significantly affect the products. The organoleptic test results in the appendix showed that the values at three different temperatures were met the standard quality of fish oil by using the assessment sheet according to National Standardization Agency of Indonesia. Consisting of a scale of 1 to 9 and had been tested by 30 panelists. The data interval results are presented in Table 8 . Based on the results, the organoleptic value of catfish oil had no significant difference.

\section{Appearance}

Based on the appearance test of striped catfish oil with different temperatures, the effects were not significantly different. The appearance test of striped catfish oil based on its organoleptic value indicated a bright, clean and golden yellow appearance. Changes in the oil purity could be affected by the presence of oil degradation products as well as material left in the oil. According to Widiyanto et al. (2015), a decrease in oil purity might be caused by oxidation of pigments (in this case, $\beta$ carotene) contained in the oil. Color pigments produced the golden yellow color of striped catfish oil. According to Eka et al. (2016), the color of fish oil was caused by color pigments, naturally present in the ingredients and extracted together, such as alpha and beta carotene (carotenoids), which caused a yellowish color.

Table 8. The organoleptic specifications in striped catfish oil

\begin{tabular}{ccccc}
\hline No. & Extraction temperature $\left({ }^{\circ} \mathrm{C}\right)$ & Appearance & Odor & Average \\
\hline 1. & 80 & $8.20 \pm 0.99^{\mathrm{a}}$ & $7.60 \pm 1.40^{\mathrm{a}}$ & $7.59<\mu<8.21$ \\
2. & 100 & $8.40 \pm 1.06^{\mathrm{a}}$ & $7.40 \pm 0.96^{\mathrm{a}}$ & $7.65<\mu<8.15$ \\
3. & 120 & $8.73 \pm 0.69^{\mathrm{a}}$ & $7.67 \pm 1.32^{\mathrm{a}}$ & $7.90<\mu<8.45$ \\
\hline
\end{tabular}

Note: Data \pm standard deviation.

The same superscript in the same column shows non-significant difference at the 5\% level

\section{Odor}

The odor test result of crude catfish oil carried out by the Kruskal-Wallis test showed ( $>0.05)$ that different temperature treatments did not affect the odor. According to the organoleptic data mean value proposed by the SNI, fish oil produces a strong specific odor. According to Widiyanto et 
al. (2015), good quality fish liver oil has a fishspecific odor but not rancid. The odor is one of the essential factors to determine whether it is acceptable or not. According to Estiasih (2009), the most critical problem in fish oil in food products is its vulnerability to oxidation, which affects aroma and flavor.

\section{CONCLUSIONS}

The different temperatures of dry rendering extraction for the crude catfish oil could affect the characteristics. The difference extraction temperatures, $80^{\circ} \mathrm{C}, 100^{\circ} \mathrm{C}$ and $120^{\circ} \mathrm{C}$, could increase the yield, free fatty acids, peroxide value and iodine value, but it was not significant in sensory properties. The moisture content, SMP and fatty acid profiles of the catfish oil were getting lower. This study produced a catfish oil with a bright, clean appearance and golden yellow color with a specific odor of fish oil. The temperature extraction at $100^{\circ} \mathrm{C}$ for 20 minutes of dry rendering produced catfish oil with $9.09 \%$ of yield, $1.44 \%$ of moisture content, $1.72 \%$ of free fatty acid, $15.82 \%$ of iodine value and the sensory properties of $7.65<\mu<8.15$.

\section{ACKNOWLEDGMENTS}

We would like to deliver our gratitude to Universitas Diponegoro for supporting this research through the APBN DPA LPPM fiscal year of 2019 under the Development and Implementation Research (RPP) scheme.

\section{REFERENCES}

Aditia, R. P., Darmanto, Y. S., \& Romadhon. (2014). Comparison of the Crude Fish Oil Quality Extracted from Various Type of Fish. Jurnal Pengolahan Dan Bioteknologi Hasil Perikanan, 3(3), 55-60. Retrieved from https://ejournal3.undip.ac.id/index.php/jpbhp/ article/view/5457

Ambrosewicz-walacik, M., Tańska, M., \& Rotkiewicz, D. (2015). Effect of heat treatment of rapeseed and methods of oil extraction on the content of phosphorus and profile of phospholipids. Polish Journal of Natural Sciences, 30(2), 123-136. Retrieved from http://www.uwm.edu.pl/polish-journal/sites/ default/files/issues/articles/ambrosewicz_wala cik_et_al.pdf
Apraku, A., Liu, L., Leng, X., Rupia, E. J., \& Ayisi, C. L. (2017). Evaluation of blended virgin coconut oil and fish oil on growth performance and resistance to Streptococcus iniae challenge of Nile tilapia (Oreochromis niloticus). Egyptian Journal of Basic and Applied Sciences, 1-10. https://doi.org/ 10.1016/j.ejbas.2017.06.002

Arika, R. (2018). Indonesian Patin Industry Goes International. Retrieved from https://komira. co.id/site/article/read/728/20/Indonesian-Patin -Industry-Goes-International

Association of Analytical Communities. (1995). Official Methods of Analysis of The Association of Official Analytical Chemist. Washington DC: AOAC Inc.

Association of Analytical Communities. (1997). Official Methods and Recommended Practices of the AOCS (5th ed.). Illinois: American Oil Chemist's Society Campaign.

Association of Analytical Communities. (2005). Official Method of Analysis of the Association of Official Analytical of Chemist. Virginia: Arlington.

Association of Analytical Communities. (2007). Official Methods of Analysis of The Association of Official Analytical Chemist. Virginia: Arlington.

Azizah, Z., Rasyid, R., \& Kartina, D. (2016). The Effect of Repetition and Storage Duration to the Rancidity of Coconut Oil by Thiobarbituric Acid Method. Jurnal Farmasi Higea, 8(2), 189-200. Retrieved from https://jurnalfarmasi higea.org/index.php/higea/article/view/150

Azka, A., Nurjanah, \& Jacoeb, A. M. (2015). Profile of fatty acids, amino acids, carotenoid total, and $\alpha$-tocopherol from flying fish eggs. JPHPI, 18(3), 250-261. https://doi.org/10. 17844/jphpi.2015.18.3.250

Badan Standardisasi Nasional. Oil and Fat Testing Procedures (1998). Indonesia.

Badan Standardisasi Nasional. Sensory Testing Instruction on Fisheries Products (2011). Indonesia.

Badan Standardisasi Nasional. Crude Sardine Fish Oil (2013). Indonesia.

Bimbo, A. P. (1998). International Fishmeal \& Oil 
Manufacturers Association. INFORM, 9(5), 473-483.

Edward, Z., Suyuthie, H., Yerizel, E., \& Sulastri, D. (2011). The Effect of High Temperatures to the Palm Oil and Corn Unsaturated Fatty Acids. Journal of the Indonesian Medical Asociation, 61(6), 248-252. Retrieved from http://garuda.ristekdikti.go.id/documents/detai $1 / 30894$

Eka, B., Junianto, \& Rochima, E. (2016). The Effect of Rendering Method to the Physial, Chemical, and Sensory Characteristics of Catfish Oil Extract. Jurnal Perikanan Kelautan, 7(1), 1-5. Retrieved from http:// jurnal.unpad.ac.id/jpk/article/view/13928

Estiasih, T. (2009). Fish Oil: Technology and Its Application for Food and Health. Yogyakarta: Graha Ilmu.

Food and Agriculture Organization of the United Nations. (2016). Sustainable Agriculture A tool to Strengthen Food Security and Nutrition in Latin America and the Caribbean. Retrieved from http://www.fao.org/3/a-i5754e.pdf

Food and Agriculture Organization of the United Nations. (2018). Sustainable Agriculture for Biodiversity, Biodiversity for Sustainable Agriculture. Retrieved from http://www.fao. org/3/a-i6602e.pdf

Ghazali, Q., \& Yasin, N. H. M. (2016). The effect of organic solvent, temperature and mixing time on the production of oil from Moringa oleifera seeds. In IOP Conference Series: Earth and Environmental Science (pp. 1-7). https://doi.org/10.1088/1755-1315/36/1/0120 53

Handajani, S., Manuhara, G. J., \& Anandito, R. B. K. (2010). Effect of extraction temperature on physical, chemical and sensory characteristics of virgin sesame oil (Sesamum indicum L.). Agritech, 30(2), 116-122. Retrieved from https://jurnal.ugm.ac.id/agritech/article/view/ 9682

Haryati. (2011). Substitution of fish meal with flour maggot on the nutrient retention, body composition, and feed efficiency in the milkfish (Chanos chanos Forskal). Jurnal Ikhtiologi Indonesia, 11(2), 185-194. Retrieved from http://jurnal-iktiologi.org/ index.php/jii/article/view/142
Hashim, R. B., Jamil, E. F., Zulkipli, F. H., \& Daud, J. M. (2015). Fatty acid compositions of silver catfish, Pangasius sp . farmed in several rivers of Pahang, Malaysia. Journal of Oleo Science, 64(2), 205-209. https://doi.org/10. 5650/jos.ess 14191

Hasibuan, H. A. (2012). The study of quality and characteristic on Indonesian palm oil and its fractionation products. Jurnal Standardisasi, 14(1), 13-21. http://dx.doi.org/10.31153/js.v $14 \mathrm{i} 1.51$

Hasibuan, H. A., \& Siahaan, D. (2013). Determination of iodine value and melting point based on solid fat content of palm oil and palm kernel oil (comparisons with AOCS standard method). Jurnal Standardisasi, 15(1), 47-57. Retrieved from http://js.bsn.go.id/ index.php/standardisasi/article/view/658

Hastarini, E., Fardiaz, D., Irianto, H. E., \& Budijanto, S. (2012). Characteristics of fish oil produced from fillet processing waste of siam (Pangasius hypopthalmus) and jambal (Pangasius djambal) catfish. Agritech, 32(4), 403-410. Retrieved from https://jurnal.ugm. ac.id/agritech/article/view/9584

Hidayati, S. (2007). The effects of temperature, cooking time, methanol concentration and purification temperature on iodine and acid numbers of palm kernel surfactant. Jurnal Teknologi Dan Industri Hasil Pertanian, 12(2), 60-64. Retrieved from http://jurnal. fp.unila.ac.id/index.php/JTHP/article/view/86

JICA. (2016). Agricultural and Rural Development / Fisheries. In JICA Annual Report (pp. 93-97). Retrieved from https:// www.jica.go.jp/english/publications/reports/a nnual/2016/c8h0vm0000aj21oz-att/2016_34. pdf

Kamini, Suptijah, P., Santoso, J., \& Suseno, S. H. (2016). Extraction by rendering Method and Characterization Fish Oil of Catfish (Pangasius hypopthalmus) Viscera Fat by Product of Smoked Fish Processing. Jurnal Pengolahan Hasil Perikanan Indonesia, 19(3), 196-205. https://doi.org/10.17844/jphpi.2016. 19.3.196

Kus-Yamashita, M. M., Filho, J. M., Mcdonald, B., Ravacci, G., Rogero, M. M., Santos, R. D., ... Lajolo, M. (2016). Polyunsaturated fatty 
acids : health impacts. European Journal of Nutrition \& Food Safety, 6(3), 111-131. https: //doi.org/10.9734/EJNFS/2016/23018

Lestari, N. (2010). Formulation and optimum condition of processing "high nutritive value" margarine from patin oil (Pangasius sp). Jurnal Riset Industri, 4(1), 35-42. Retrieved from https://kemenperin.go.id/download/4779 /Jurnal-Riset-Industri-Vol-4,-No-1-(2010):Standardisasi-dan-Regulasi-Teknis

Monge-Ortiz, R., Tomás-Vidal, A., RodriguezBarreto, D., Martínez-Llorens, S., Pérez, J. A., Jover-Cerdá, M., \& Lorenzo, A. (2018). Replacement of Fish Oil with Vegetable Oil Blends in Feeds for Greater Amberjack (Seriola dumerili) Juveniles: Effect on Growth Performance, Feed Efficiency, Tissue Fatty Acid Composition and Flesh Nutritional Value. Aquaculture Nutrition, 24(1), 605-615. https://doi.org/10.1111/anu.12595

Ngadiarti, I., Kusharto, C. M., Briawan, D., Marliyati, S. A., \& Sayuthi, D. (2013). Fatty acid contents and physico-chemical characteristics of catfish oil and fermented catfish oil. Penelitian Gizi Dan Makanan, 36(1), 82-90. Retrieved from http://ejournal .litbang.depkes.go.id/index.php/pgm/article/vi ew/3398

Nugroho, A. J., Ibrahim, R., \& Riyadi, P. H. (2014). The Effect of Different Steaming Temperature (Steam Jacket) Toward Crude Fish Oil Quality from Waste of Tilapia (Oreochromis niloticus) Intestine. Jurnal Pengolahan Dan Bioteknologi Hasil Perikanan, 3(1), 21-29. Retrieved from https://ejournal3.undip.ac.id/index.php/jpbhp/ article/view/4818

Nurjanah, Suseno, S. H., \& Arifianto, T. B. (2014). Extraction and Characterization of Fish Oil from Catfish (Pangasius hypopthalmus) skin. Depik, 3(3), 250-262. https://doi.org/10.13170/depik.3.3.2152

Panagan, A. T., Yohandini, H., \& Gultom, J. U. (2011). Qualitative and Quantitative Analysis of Omega-3 Unsaturated Fatty Acid from Catfish Oil (Pangasius pangasius) by Gas Chromatography Method. Jurnal Penelitian Sains, 14(4), 38-42. Retrieved from http:// ejurnal.mipa.unsri.ac.id/index.php/jps/article/ view/204
Pike, I. H., \& Jackson, A. (2010). Fish oil: production and use now and in the future. Lipid Technology, 22(3), 59-61. https://doi.org/10. 1002/lite.201000003

Rozi, A., Suseno, S. H., \& Jacoeb, A. M. (2016). Extraction and characterization of liver oil from silky shark. JPHPI, 19(2), 100-109. https://doi.org/10.17844/jphpi.2016.19.2.100

Saleem, M., \& Ahmad, N. (2018). Characterization of canola oil extracted by different methods using fluorescence spectroscopy. Plos One, 13(2), 1-16. https:// doi.org/10.1371/journal.pone.0208640

Santhanam, A. K., Lekshmi, M., Chouksey, M. K., \& Tripathi, G. (2015). Delivery of omega3 fatty acids into cake through emulsification of fish oil-in-milk and encapsulation by spray drying with added polymers. Drying Technology: An International Journal, 33, 8391. https://doi.org/10.1080/07373937.2014.93 4832

Sartika, R. A. D. (2008). The Effect of Saturated, Unsaturated, and Trans Fatty Acid on Health. Kesmas: National Public Health Journal, 2(4), 154-160. https://doi.org/10.21109/kesmas.v2 i4. 258

Subroto, E., Tensiska, Indiarto, R., Marta, H., \& Wulan, A. S. (2018). Physicochemical and sensorial properties of recombined butter produced from milk fat and fish oil blend. Bioscience Research, 15(4), 3733-3740. Retrieved from https://www.isisn.org/BR15 (4)2018/3733-3740-15(4)2018BR18-612.pdf

Suroso, A. S. (2013). The Quality of Used Cooking Oil Reviewed by Peroxide Value, Acid Value, and Moisture Content. Jurnal Kefarmasian Indonesia, 3(2), 77-88. Retrieved from http://ejournal.litbang.depkes. go.id/index.php/jki/article/view/4058

Suseno, S. H., Musbah, M., \& Ruspatti, N. P. (2016). The Characteristic of Sardine (Sardinella sp.) and Swordfish (Centrophorus sp.) Oil as Omega-3 and Squalene Rich Food Supplement. In Seminar Nasional Kelautan (pp. 48-56). Madura. Retrieved from http:// ilmukelautan.trunojoyo.ac.id/wp-content/uplo ads/2016/08/8_Prosiding_semnaskel_2016. pdf

Thammapat, P., Raviyan, P., \& Siriamornpun, S. 
(2010). Proximate and fatty acids composition of the muscles and viscera of Asian catfish (Pangasius bocourti). Food Chemistry, 122, 223-227. https://doi.org/10.1016/j.foodchem. 2010.02.065

Ulfah, M., Ruswanto, A., \& Ngatirah. (2016). Characteristics of oil blends from red palm oil and palm kernel olein. Agritech, 36(2), 145153. https://doi.org/10.22146/agritech.12858

Widiyanto, W. N., Ibrahim, R., \& Anggo, A. D. (2015). The effect of processing temperature of simple steam jacket on the quality of white spotted whipray rays liver oil. Jurnal Pengolahan Hasil Perikanan Indonesia, 18(1), 11-18. https://doi.org/10.17844/jphpi.2015.18

\section{.1 .11}

Wulandari, N., Muchtadi, T. R., Budijanto, S., \& Sugiyono. (2011). Physical properties of crude palm oil and their correlations to the quality attributes. Jurnal Teknologi Dan Industri Pangan, 22(2), 177-183. Retrieved from http://journal.ipb.ac.id/index.php/jtip/article/v iew/4274

Zhong, J., Yang, R., Cao, X., Liu, X., \& Qin, X. (2018). Improved Physicochemical Properties of Yogurt Fortified with Fish Oil $/ \gamma$-Oryzanol by Nanoemulsion Technology. Molecules, 23(1), 56-67. https://doi.org/10.3390/molecu les 23010056 